\title{
RANCANG BANGUN PAKET IPAL RUMAH SAKIT DENGAN PROSES BIOFILTER ANAEROB-AEROB, KAPASITAS 20-30 M³ PER HARI
}

\author{
Oleh : \\ Wahyu Widayat dan Nusa Idaman Said \\ Kelompok Teknologi Pengelolaan Air Bersih dan Limbah Cair, Pusat Pengkajian dan Penerapan
Teknologi Lingkungan, BPPT
}

\begin{abstract}
It is obvious that hospital waste water is one of the most potential pollutant to the evironment. Thus the waste must be treated properly before it is disposed of to the public sewage facilities. However, limited fund usually become an obstacle when hospitals will construct waste treatment facilities, especially for midle and small typed hospitals.

Considering the problem, development of proper waste treatment facilities which is cheap in terms of technology and price and easy operated is very important.

This paper describes scheme of biological waste water treatment unit for hospitals which is suitable for Anaerob-aerob Biofilter waste water treatment process. By applying this sistemAnaerob-aerob Biofilter, concentration of $C O D, B O D$ and suspended solid material can be reduced significantly as well as detergen and ammonia.
\end{abstract}

Kata kunci : rancang bangun, air limbah, biofilter, anaerob-aerob

\section{PENDAHULUAN}

\subsection{Latar abelakang Masalah}

Berdasarkan keputusan Mentreri Negara Lingkungan Hidup Republik Indonesia Nomor : Kep-58/MENLH/12/1995 tentang Baku Mutu Limbah Cair bagi kegiatan Rumah Sakit, yang mengharuskan bahwa setiap rumah sakit harus mengolah air limbah sampai standar yang diijinkan, maka kebutuhan akan teknologi pengolahan air limbah rumah sakit khususnya yang murah dan hasilnya baik perlu dikembangkan. Hal ini mengingat bahwa kendala yang paling banyak dijumpai yakni teknologi yang ada saat ini masih cukup mahal, sedangkan di lain pihak dana yang tersedia untuk membangun unit alat pengolah air limbah tersebut sangat terbatas sekali. Untuk rumah sakit dengan kapasitas yang besar umumnya dapat membangun unit alat pengolah air limbahnya sendiri karena mereka mempunyai dana yang cukup. Tetapi untuk rumah sakit tipe kecil sampai dengan tipe sedang umumnya sampai saat ini masih membuang air limbahnya ke saluran umum tanpa pengolahan sama sekali.

Untuk mengatasi hal tersebut maka perlu dikembangkan teknologi pengolahan air limbah rumah sakit yang murah, mudah operasinya serta harganya terjangkau, khususnya untuk rumah sakit dengan kapasitas kecil sampai sedang. Untuk mencapai tujuan tersebut, terdapat kedala yang cukup besar yakni kurangnya tersedianya teknologi pengolahan yang baik dan harganya murah. Masalah ini menjadi kendala yang cukup besar terutama untuk rumah sakit kecil, yang mana pihak rumah sakit tidak/belum mampu untuk membangun unit alat pengilahan air limbah sendiri, sehingga sampai saat ini masih banyak sekali rumah sakit yang membuang air limbahnya ke saluran umum.

Untuk pengolahan air limbah rumah sakit dengan kapasitas yang besar, umumnya menggunakan teknlogi pengolahan air limbah "Lumpur Aktif" atau Activated Sludge Process, tetapi untuk kapasitas kecil cara tersebut kurang ekonmis karena biaya operasinya cukup besar, kontrol oprasionalnya lebih sulit.

Untuk mengatasi hal tersebut, perlu menyebarluaskan informasi teknologi khususya teknologi pengolahan air limbah rumah sakit berserta aspek pemilihan teknologi serta keunggulan dan kekurangannya. Dengan adanya informasi yang jelas, maka pihak pengelola rumah sakit dapat memilih teknologi pengolahan limbah yang sesuai dengan kodisi maupun jumlah air limbah yang akan diolah, yang layak secara teknis, ekonomis dan memenuhi standar lingkungan.

\subsection{Tujuan Studi}

Tujuan dari kegiatan ini adalah membuat rancang bangun paket instalsi pengolahan air limbah (IPAL) rumah sakit, kapasitas 20-30 $\mathrm{m} 3$ /hari dengan dengan proses Kombinasi Biofilter anaerob-aerob

Sasaran kegiatan ini adalah membuat paket percontohan IPAL Rumag sakit yang murah dan handal dengan menggunakan proses biofilter anaerob-aerob. 


\section{$1.3 \quad$ Metodologi}

- Mempelajari studi-studi terdahulu tentang kualitas air limbah rumah sakit.

- Melakukan rancang bangun IPAL rumah sakit kapasitas $20 \mathrm{~m} 3 /$ hari dengan menerapkan sistem Kombinasi proses biofilter anaerob-aerob

- Membuat paket percontohan instalasi pengolahan air limbah rumah sakit kapasitas 20-30 $\mathrm{M}^{3}$ per hari.

- Uji coba, analisa sampel air influent dan effluent

\section{KARAKTERISTIK AIR LIMBAH RUMAH SAKIT}

Air limbah rumah sakit adalah seluruh buangan cair yang berasal dari hasil proses seluruh kegiatan rumah sakit yang meliputi: limbah domistik cair yakni buangan kamar mandi, dapur, air bekas pencucian pakaian; limbah cair klinis yakni air limbah yang berasal dari kegiatan klinis rumah sakit misalnya air bekas cucian luka, cucian darah dll.; air limbah laboratorium; dan lainya. Air limbah rumah sakit yang berasal dari buangan domistik maupun buangan limbah cair klinis umumnya mengadung senaywa pulutan organik yang cukup tinggi, dan dapat diolah dengan proses pengolahan secara biologis, sedangkan untuk air limbah rumah sakit yang berasal dari laboratorium biasanya banyak mengandung logam berat yang mana bila air limbah tersebut dialirkan ke dalam proses pengolahan secara biologis, logam berat tersebut dapat menggagu proses pengolahannya. Oleh karena itu untuk pengelolaan air limbah rumah sakit, maka air limbah yang berasal dari laboratorium dipisahkan dan ditampung, kemudian diolah secara kimiafisika, Selanjutnya air olahannya dialirkan bersama-sama dengan air limbah yang lain, dan selanjutnya diolah dengan proses pengolahan secara biologis. Diagram proses pengelolaan air limbah rumah sakit secara umum dapat dilihat seperti pada Gambar 1.

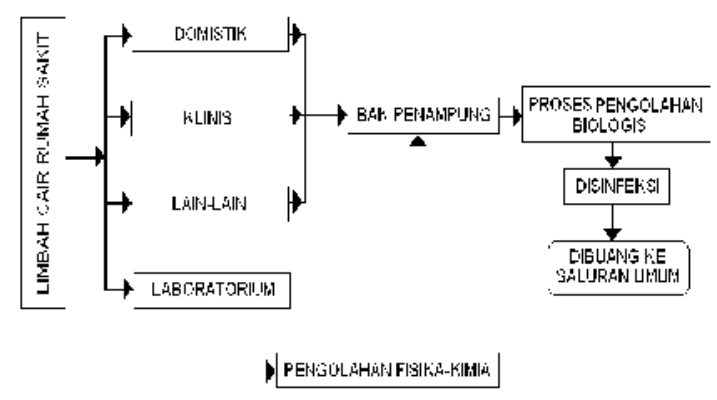

Gambar 1 : Diagram proses pengelolaan air limbah rumah sakit
Dari hasil analisa kimia terhadap berberapa contoh air limbah rumah sakit yang ada di DKI Jakarta menunjukkan bahwa konsentrasi senywa pencemar sangat bervariasi misalnya, BOD 31,52 - 675,33 mg/l, ammoniak $10,79-158,73 \mathrm{mg} / \mathrm{l}$, deterjen (MBAS) 1,66 - 9,79 $\mathrm{mg} / \mathrm{l}$. Hal ini mungkin disebabkan karena sumber air limbah juga bervarisi sehingga faktor waktu dan metoda pengambilan contoh sangat mempengaruhi besarnya konsentarsi.

\section{TEKNOLOGI PENGOLAHAN AIR LIMBAH}

Untuk mengolah air yang mengandung senyawa organik umumnya menggunakan teknologi pengolahan air limbah secara biologis atau gabungan antara proses biologis dengan proses kimia-fisika. Proses secara biologis tersebut dapat dilakukan pada kondisi aerobik (dengan udara), kondisi anaerobik (tanpa udara) atau kombinasi anaerobik dan aerobik. Proses biologis aeorobik biasanya digunakan untuk pengolahan air limbah dengan beban BOD yang tidak terlalu besar, sedangkan proses biologis anaerobik digunakan untuk pengolahan air limbah dengan beban BOD yang sangat tinggi. Dalam makalah ini uraian dititik beratkan pada proses pengolahan air limbah secara aerobik.

Pengolahan air limbah secara biologis aerobik secara garis besar dapat dibagi menjadi tiga yakni proses biologis dengan biakan tersuspensi (suspended culture), proses biologis dengan biakan melekat (attached culture) dan proses pengolahan dengan sistem lagoon atau kolam.

Proses biologis dengan biakan tersuspensi adalah sistem pengolahan dengan menggunakan aktifitas mikro-organisme untuk menguraikan senyawa polutan yang ada dalam air dan mikro-organime yang digunakan dibiakkan secara tersuspesi di dalam suatu reaktor. Beberapa contoh proses pengolahan dengan sistem ini antara lain : proses lumpur aktif standar/konvesional (standard activated sludge), step aeration, contact stabilization, extended aeration, oxidation ditch (kolam oksidasi sistem parit) dan lainya.

Proses biologis dengan biakan melekat yakni proses pengolahan limbah dimana mikroorganisme yang digunakan dibiakkan pada suatu media sehingga mikroorganisme tersebut melekat pada permukaan media. Beberapa contoh teknologi pengolahan air limbah dengan cara ini antara lain : trickling filter atau biofilter, rotating biological contactor (RBC), contact aeration/oxidation (aerasi kontak) dan lainnnya.

Proses pengolahan air limbah secara biologis dengan lagoon atau kolam adalah 
dengan menampung air limbah pada suatu kolam yang luas dengan waktu tinggal yang cukup lama sehingga dengan aktifitas mikroorganisme yang tumbuh secara alami, senyawa polutan yang ada dalam air akan terurai. Untuk mempercepat proses penguraian senyawa polutan atau memperpendek waktu tinggal dapat juga dilakukam proses aerasi. Salah satu contoh proses pengolahan air limbah dengan cara ini adalah kolam aerasi atau kolam stabilisasi (stabilization pond). Proses dengan sistem lagoon tersebut kadang-kadang dikategorikan sebagai proses biologis dengan biakan tersuspensi.

Secara garis besar klasifikasi proses pengolahan air limbah secara umum dapat dilihat seperti pada Gambar 2,

KLASIFIKASI PROEES PENGOLAHAN AIR LIIIBAAH SECARA BIOLOGIS

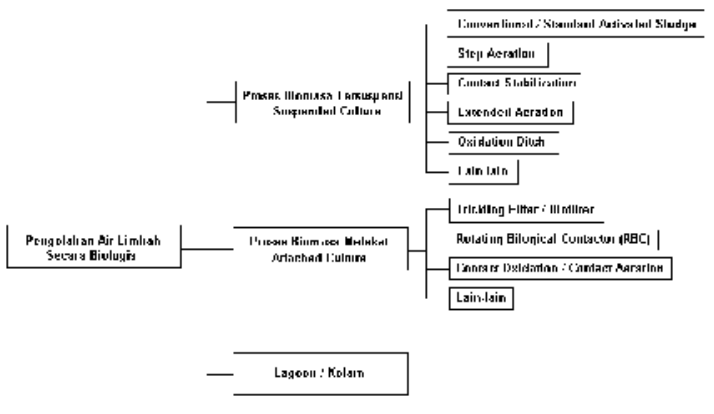

Gambar 2 : Klasifikasi proses pengolahan air limbah secara biologis aerobik.

Berdasarkan beberapa macam proses pengolahan air limbah seperti uraian di atas, untuk proses pengolahan air limbah Rumah Sakit tipe kecil sampai sedang proses pengolahan yang paling sesuai yakni proses pengolahan dengan Sistem Kombinasi Biofilter Anaerob dan Aerob.

Beberapa keunggulan proses pengolahan air limbah dengan biofilter anaerb-aerob antara lain yakni :

- Pengelolaannya sangat mudah.

- Biaya operasinya rendah.

- Dibandingkan dengan proses lumpur aktif, Lumpur yang dihasilkan relatif sedikit.

- Dapat menghilangkan nitrogen dan phospor yang dapat menyebabkan euthropikasi.

- Suplai udara untuk aerasi relatif kecil.

- Dapat digunakan untuk air limbah dengan beban BOD yang cukup besar.

- Dapat menghilangan padatan tersuspensi (SS) dengan baik.

\subsection{Pengolahan air Limbah Dengan Proses Biofilter Anaerob-Aerob}

Seluruh air limbah yang dihasilkan oleh kegiatan rumah sakit, yakni yang berasal dari limbah domistik maupun air limbah yang berasal dari kegiatan klinis rumah sakit dikumpulkan melalui saluran pipa pengumpul. Selanjutnya dialirkan ke bak kontrol. Fungsi bak kontrol adalah untuk mencegah sampah padat misalnya plastik, kaleng, kayu agar tidak masuk ke dalam unit pengolahan limbah, serta mencegah padatan yang tidak bisa terurai misalnya lumpur, pasir, abu gosok dan lainnya agar tidak masuk kedalam unit pengolahan limbah.

Dari bak kontrol, air limbah dialirkan ke bak pengurai anaerob. Bak pengurai anaerob dibagi menjadi dua buah ruangan yakni bak pengendapan atau bak pengurai awal, biofilter anaerob tercelup dengan aliran dari bawah ke atas (Up Flow. Air limpasan dari bak pengurai anaerob selanjutnya dialirkan ke unit pengolahan lanjut. Unit pengolahan lanjut tersebut terdiri dari beberapa buah ruangan yang berisi media dari bahan PVC bentuk sarang tawon untuk pembiakan mikro-organisme yang akan menguraikan senyawa polutan yang ada di dalan air limbah.

Setelah melalui unit pengolahan lanjut, air hasil olahan dialirkan ke bak khlorinasi. Di dalam bak khlorinasi air limbah dikontakkan dengan khlor tablet agar seluruh mikroorganisme patogen dapat dimatikan. Dari bak khlorinasi air limbah sudah dapat dibuang langsung ke sungai atau saluran umum.

\subsubsection{PENGURAIAN ANAEROB}

Air limbah yang dihasilkan dari proses kegiatan rumah sakit atau puskesmas dikumpulkan melalui saluran air limbah, kemudian dilairkan ke bak kontrol untuk memisahkan kotoran padat. Selanjutnya, sambil di bubuhi dengan larutan kapur atau larutan $\mathrm{NaOH}$ air limbah dialirkan ke bak pengurai anaerob. Di dalam bak pengurai anaerob tersebut polutan organik yang ada di dalam air limbah akan diuraikan oleh mikroorganisme secara anaerob, menghasilkan gas methan dan $\mathrm{H}_{2} \mathrm{~S}$. Dengan proses tahap pertama konsentrasi COD dalam air limbah dapat diturukkan sampai kira-kira 400-500 ppm (efisiensi pengolahan \pm 60-70\%). Air olahan tahap awal ini selanjutnya diolah dengan proses pengolahan lanjut dengan sistem biofilter anaerob-aerob.

\subsubsection{PROSES PENGOLAHAN LANJUT}

Proses pengolahan lanjut ini dilakukan dengan sistem biofilter anaerob-aerob. Pengolahan air limbah dengan proses biofilter anaerob-aerob terdiri dari beberapa bagian yakni bak pengendap awal, biofilter anaerob (anoxic), 
biofilter aerob, bak pengendap akhir, dan jika perlu dilengkapi dengan bak kontaktor khlor. Air limbah yang berasal dari proses penguraian anaerob (pengolahan tahap perama) dialirkan ke bak pengendap awal, untuk mengendapkan partikel lumpur, pasir dan kotoran lainnya. Selain sebagai bak pengendapan, juga berfungasi sebagai bak pengontrol aliran, serta bak pengurai senyawa organik yang berbentuk padatan, sludge digestion (pengurai lumpur) dan penampung lumpur.

Air limpasan dari bak pengendap awal selanjutnya dialirkan ke bak kontaktor anaerob dengan arah aliran dari atas ke dan bawah ke atas. $\mathrm{Di}$ dalam bak kontaktor anaerob tersebut diisi dengan media dari bahan plastik berbentuk sarang tawon. Jumlah bak kontaktor anaerob ini bisa dibuat lebih dari satu sesuai dengan kualitas dan jumlah air baku yang akan diolah. Penguraian zat-zat organik yang ada dalam air limbah dilakukan oleh bakteri anaerobik atau facultatif aerobik Setelah beberapa hari operasi, pada permukaan media filter akan tumbuh lapisan film mikro-organisme. Mikroorganisme inilah yang akan menguraikan zat organik yang belum sempat terurai pada bak pengendap.

Air limpasan dari bak kontaktor anaerob dialirkan ke bak kontaktor aerob. Di dalam bak kontaktor aerob ini diisi dengan media dari bahan kerikil, plastik (polyethylene), batu apung atau bahan serat, sambil diaerasi atau dihembus dengan udara sehingga mikro organisme yang ada akan menguraikan zat organik yang ada dalam air limbah serta tumbuh dan menempel pada permukaan media. Dengan demikian air limbah akan kontak dengan mikro-orgainisme yang tersuspensi dalam air maupun yang menempel pada permukaan media yang mana hal tersebut dapat meningkatkan efisiensi penguraian zat organik, deterjen serta mempercepat proses nitrifikasi, sehingga efisiensi penghilangan ammonia menjadi lebih besar. Proses ini sering di namakan Aerasi Kontak (Contact Aeration). Dari bak aerasi, air dialirkan ke bak pengendap akhir. Di dalam bak ini lumpur aktif yang mengandung massa mikroorganisme diendapkan dan dipompa kembali ke bagian inlet bak aerasi dengan pompa sirkulasi lumpur. Sedangkan air limpasan (over flow) dialirkan ke bak khlorinasi. Di dalam bak kontaktor khlor ini air limbah dikontakkan dengan senyawa khlor untuk membunuh mikroorganisme patogen. Air olahan, yakni air yang keluar setelah proses khlorinasi dapat langsung dibuang ke sungai atau saluran umum. Dengan kombinasi proses anaerob dan aerob tersebut selain dapat menurunkan zat organik (BOD, COD), ammonia, deterjen, padatan tersuspensi (SS), phospat dan lainnya. Dengan adanya proses pengolahan lanjut tersebut konsentrasi BOD dalam air olahan yang dihasilkan relatif rendah yakni sekitar 20-30 ppm.

\section{PERHITUNGAN PERENCANAAN IPAL RUMAH SAKIT KAPASITAS $20 \mathrm{M}^{3}$ PER HARI}

\subsection{Kapasitas Disain}

Unit alat ini dirancang untuk dapat mengolah air limbah sebesar $20 \mathrm{~m}^{3} / \mathrm{hari}$. Skenario proses IPAL serta reduksi polutan organik (BOD) ditunjukkan seperti pada Gambar 3.

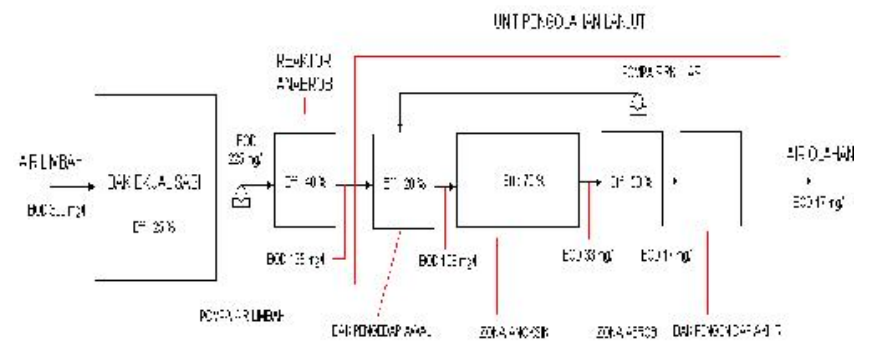

Gambar 3 : Skenario proses IPAL serta reduksi polutan organik (BOD).

\subsection{Perhitungan Disain IPAL}

$\begin{array}{ll}\text { Kapasitas Rencana } & : 20 \mathrm{~m}^{3} \text { per hari. } \\ \text { BOD Masuk } & : 400 \mathrm{mg} / \mathrm{lt} . \\ \text { SS Masuk } & : 200 \mathrm{mg} / \mathrm{lt} \\ \text { Efisiensi Pengolahan } & : 90-95 \% \\ \text { BOD keluar } & : 20 \mathrm{mg} / \mathrm{lt} \\ \text { SS keluar } & : 20 \mathrm{mg} / \mathrm{tt}\end{array}$

\subsubsection{Bak ekualisasi}

\begin{tabular}{ll} 
Kapasitas Rencana & $: 20$ per hari. \\
BOD Masuk & $: 400 \mathrm{mg} / \mathrm{lt}$. \\
BOD keluar & $: 400 \mathrm{mg} / \mathrm{lt}$ \\
Waktu Tinggal (WTH) & $: 12 \mathrm{jam}$ \\
Volume bak & $: 10 \mathrm{~m}^{3}$ \\
Dimensi bak : & \\
$\quad$ Lebar & $: 2,0 \mathrm{~m}$ \\
$\quad$ Panjang & $: 2,5 \mathrm{~m}$ \\
$\quad$ Kedalaman & $: 2 \mathrm{~m}$ \\
\multicolumn{1}{c}{ Tinggi ruang bebas $: 0,5 \mathrm{~m}$}
\end{tabular}

Chek Waktu Tinggal : 12 jam

\subsubsection{Pompa Air Limbah}

$\begin{array}{ll}\text { Kapasitas } & : 20 \mathrm{M} 3 / \text { hari } \\ \text { Tipe } & : \text { Pompa Celup } \\ \text { Total Head } & : 9 \text { meter } \\ \text { Jumlah } & : 1 \text { buah } \\ \text { Listrik } & : 250 \text { watt, } 220-240 \text { volt }\end{array}$




\subsubsection{Biofilter Anaerob}

$$
\begin{array}{ll}
\text { BOD Masuk } & : 400 \mathrm{mg} / \mathrm{lt} . \\
\text { Efisiensi Pengolahan } & : 60 \% \\
\text { BOD keluar } & : 160 \mathrm{mg} / \mathrm{lt}
\end{array}
$$

Untuk pengolahan air dengan proses biofilter standar Beban BOD per volume media 0,4-4,7 $\mathrm{kg} \mathrm{BOD} / \mathrm{m}^{3}$.hari.

Ditetapkan beban BOD yang digunakan $2,5 \mathrm{~kg}$ $\mathrm{BOD} / \mathrm{m}^{3}$.hari.

Beban BOD di dalam air limbah $=20 \mathrm{~m}^{3} /$ hari $X$ $400 \mathrm{~g} / \mathrm{m}^{3}=8.000 \mathrm{~g} / \mathrm{hari}=8 \mathrm{~kg} / \mathrm{hari}$

Volume media yang diperlukan $=$

$$
8 \mathrm{~kg} / \mathrm{hari}
$$

Volume Media $=70 \%$ dari total Volume rekator. Volume Reaktor yang diperlukan $=10 / 7 \times 3,2 \mathrm{~m}^{3}$ $=4,6 \mathrm{~m}^{3}$

Waktu Tinggal Reaktor Anaerob yang dibutuhkan :

$$
\begin{aligned}
& =\frac{4,6 \mathrm{~m}^{3}}{20 \mathrm{~m}^{3} / \text { hari }} \times 24 \text { jam } / \text { hari }= \\
& =5,52 \mathrm{jam}
\end{aligned}
$$

Dimensi :

$\begin{array}{ll}\text { Lebar } & : 1,5 \mathrm{~m} \\ \text { Panjang } & : 1,5 \mathrm{~m} \\ \text { Kedalaman air efektif } & : 2,0 \mathrm{~m} \\ \text { Ruang Bebas } & : 20 \mathrm{~cm}\end{array}$

\subsubsection{Pengolahan Lanjut}

\section{A. Bak Pengendapan Awal}

$\begin{array}{ll}\text { Kapasitas Rencana } & : 20 \mathrm{~m}^{3} \text { per hari. } \\ \text { BOD Masuk } & : 160 \mathrm{mg} / \mathrm{lt} . \\ \text { Efisiensi Pengolahan } & : 25 \% \\ \text { BOD keluar } & : 120 \mathrm{mg} / \mathrm{lt} \\ \text { Waktu Tinggal (WTH) } & : 2 \mathrm{jam} \\ \text { Volume bak } & : 1,67 \mathrm{~m}^{3}\end{array}$

Dimensi bak :

$\begin{array}{ll}\text { Lebar } & : 1,5 \mathrm{~m} \\ \text { Panjang } & : 0,6 \mathrm{~m} \\ \text { Tinggi } & : 2,2 \mathrm{~m} \\ \text { Kedalaman Air efektif } & : 2,0 \mathrm{~m}\end{array}$

Chek :

Waktu Tinggal (Retention Time) rata-rata $= \pm$ 2,162 Jam

Beban permukaan (surface loading) rata-rata $=$ 22,2 m3/m2.hari
- Standar :

Waktu tinggal $=2$ jam

Beban permukaan $=20-50 \mathrm{~m} 3 / \mathrm{m} 2$. hari. (JWWA)

\section{B. Biofilter Zona Anoksik (Anaerob)}

$\begin{array}{ll}\text { Kapasitas Rencana } & : 20 \mathrm{~m}^{3} \text { per hari. } \\ \text { BOD Masuk } & : 120 \mathrm{mg} / \mathrm{lt} . \\ \text { Efisiensi Pengolahan } & : 60 \% \\ \text { BOD keluar } & : 48 \mathrm{mg} / \mathrm{lt}\end{array}$

Untuk pengolahan air dengan proses biofilter standar Beban BOD per volume media 0,4-4,7 $\mathrm{kg} \mathrm{BOD} / \mathrm{m}^{3}$.hari.

Ditetapkan beban BOD yang digunakan $=1,0 \mathrm{~kg}$ $\mathrm{BOD} / \mathrm{m}^{3}$.hari.

Beban BOD di dalam air limbah $=20 \mathrm{~m}^{3} /$ hari $X$ $120 \mathrm{~g} / \mathrm{m}^{3}=2.400 \mathrm{~g} / \mathrm{hari}=2,4 \mathrm{~kg} /$ hari

Volume media yang diperlukan $=$

$$
=\frac{2,4 \mathrm{~kg} / \text { hari }}{1,0 \mathrm{~kg} / \mathrm{m}^{3} \cdot \text { hari }}=2,4 \mathrm{~m}^{3} \text {. }
$$

Volume Media $=60 \%$ dari total Volume rekator, Volume Reaktor yang diperlukan $=10 / 6 \times 2,4 \mathrm{~m}^{3}$ $=4,0 \mathrm{~m}^{3}$

Waktu Tinggal Reaktor Anaerob yang dibutuhkan $=$

$$
20 \mathrm{~m}^{3} / \text { hari }
$$

Dimensi :

$\begin{array}{ll}\text { Lebar } & : 1,5 \mathrm{~m} \\ \text { Panjang } & : 1,4 \mathrm{~m} \\ \text { Kedalaman air efektif } & : 2,0 \mathrm{~m} \\ \text { Tinggi ruang bebas } & : 0,2 \mathrm{~m} \\ \text { Jumlah ruang } & : \text { di bagi menjadi } 2 \\ \text { ruangan } & \end{array}$

Chek : Waktu tinggal rata-rata $=4,8$ jam

- Tinggi ruang lumpur $=0,2 \mathrm{~m}$

- $\quad$ Tinggi Bed media pembiakan mikroba $=1,5$ $m$

- Tinggi air di atas bed media $=30 \mathrm{~cm}$

- Volume media pada biofilter anaerob $=3,6$ m3.

- $\quad$ BOD Loading per volume media $=1,0 \mathrm{Kg}$ $\mathrm{BOD} / \mathrm{m}^{3}$.hari.

Standar high rate trickling filter : $0,4-4,7 \mathrm{~kg}$ $\mathrm{BOD} / \mathrm{m}^{2}$.hari. (Ebie Kunio, 1995) 


\section{Biofilter Aerob}

$\begin{array}{ll}\text { Kapasitas Rencana: } & : 20 \mathrm{~m}^{3} \text { per hari. } \\ \text { BOD Masuk } & : 48 \mathrm{mg} / \mathrm{lt} . \\ \text { Efisiensi Pengolahan } & : 50 \% \\ \text { BOD keluar } & : 24 \mathrm{mg} / \mathrm{lt}\end{array}$

Untuk pengolahan air dengan proses biofilter standar Beban BOD per volume media 0,4-4,7 $\mathrm{kg} \mathrm{BOD} / \mathrm{m}^{3}$.hari.

Ditetapkan beban BOD yang digunakan $=1,0 \mathrm{~kg}$ $\mathrm{BOD} / \mathrm{m}^{3}$.hari.

Beban BOD di dalam air limbah $=20 \mathrm{~m}^{3} /$ hari $X$ $48 \mathrm{~g} / \mathrm{m}^{3}=960 \mathrm{~g} / \mathrm{hari}=0,96 \mathrm{~kg} / \mathrm{hari}$.

Jumlah BOD yang dihilangkan $=0,5 \times 0,96$

$\mathrm{kg} / \mathrm{hari}=0,48 \mathrm{~kg} / \mathrm{hari}$.

Beban $\mathrm{BOD}$ per volume media yang digunakan $=$ $1,0 \mathrm{~kg} / \mathrm{m}^{3}$.hari.

Volume media yang diperlukan $=$

$$
=\frac{0,96 \mathrm{~kg} / \text { hari }}{1,0 \mathrm{~kg} / \mathrm{m}^{3} \text {.hari }}=0,96 \mathrm{~m}^{3} \text {. }
$$

Volume media $=0,5$ Volume Reaktor $\rightarrow \rightarrow$

Voleme Reaktor Biofilter Areob Yang diperlukan $=10 / 5 \times 0,96 \mathrm{~m}^{3}=1,92 \mathrm{~m}^{3}$

- Dimensi Reaktor Biofilter Areob :

$\begin{array}{ll}\text { Lebar } & : 1,5 \mathrm{~m} \\ \text { Panjang } & : 0,7 \mathrm{~m} \\ \text { Kedalan air efektif } & : 2,0 \mathrm{~m} \\ \text { Tinggi ruang bebas } & : 0,2 \mathrm{~m}\end{array}$

Chek :

- Waktu tinggal total rata-rata $\pm 2,52$ jam

- Tinggi ruang lumpur $0,2 \mathrm{~m}$

- Tinggi Bed media pembiakan mikroba 1,5 m

- Tinggi air di atas bed media $30 \mathrm{~cm}$

- Reaktor dibagi menjadi dua ruangan yakni ruangan aerasi dan ruangan biofilter.

- Volume total media pada biofilter aerob $=1,5$ $\mathrm{m} \times 0,6 \mathrm{~m} \times 1,5 \mathrm{~m}=1,35 \mathrm{~m}^{3}$

Chek :

BOD Loading per volume media $=0,71 \mathrm{Kg}$ $\mathrm{BOD} / \mathrm{m}^{3}$.hari.

Standar high rate trickling filter : $0,4-4,7 \mathrm{~kg}$ $\mathrm{BOD} / \mathrm{m}^{2}$.hari.

\section{Kebutuhan Oksigen :}

Kebutuhan oksigen di dalam reaktor biofilter aerob sebanding dengan jumlah BOD yang dihilangkan.
Jadi : Kebutuhan teoritis = Jumlah BOD yang dihilangkan

$$
=0,48 \mathrm{~kg} / \mathrm{hari} \text {. }
$$

Faktor keamanan ditetapkan $\pm 1,4 \rightarrow$

Kebutuhan Oksigen Teoritis $=1,4 \times 0,48 \mathrm{~kg} /$ hari $=0,672 \mathrm{~kg} / \mathrm{hari}$.

Temperatur udara rata-rata $=28^{\circ} \mathrm{C}$

Berat Udara pada suhu $28^{\circ} \mathrm{C}=1,1725 \mathrm{~kg} / \mathrm{m}^{3}$.

Di asumsikan jumlah oksigen didalam udara 23,2 $\%$. $\rightarrow$

Jadi :

Jumlah Kebutuhan Udara teoritis $=$ $0,672 \mathrm{~kg} / \mathrm{hari}$

$1,1725 \mathrm{~kg} / \mathrm{m}^{3} \times 0,232 \mathrm{~g} \mathrm{O}_{2} / \mathrm{g}$ Udara

$=2,47 \mathrm{~m}^{3} /$ hari.

Efisiensi Difuser $=2,5 \%$

Kebutuhan Udara Aktual $=$

$$
\begin{array}{ll}
2,47 \mathrm{~m}^{3} / \text { hari } & =98,8 \mathrm{~m}^{3} / \text { hari } \\
0,025 & =0,069 \mathrm{~m}^{3} / \text { menit. }
\end{array}
$$

Chek :

Ratio Volume Udara /Volume Air Limbah $=4,94$

Blower Udara Yang diperlukan :

Jika efisiesnsi blower dianggap $60 \%$, maka diperlukan blower dengan spesifikasi sbb:

Spesifikasi Blower :

$\begin{array}{ll}\text { Kapasitas } & =0,069 \mathrm{~m}^{3} / \text { menit } \\ \text { Head } & =2000 \mathrm{~mm} \text {-aqua } \\ \text { Jumlah } & =2 \text { unit }\end{array}$

Difuser :

Total transfer udara $=0,069 \mathrm{~m}^{3} /$ menit $=69$

liter/menit

Tipe Difuser yang digunakan : difuser gelembung kasar

\section{Bak Pengendap Akhir}

$\begin{array}{ll}\text { Kapasitas Rencana } & : 20 \mathrm{~m}^{3} \text { per hari. } \\ \text { BOD Masuk } & : 24 \mathrm{mg} / \mathrm{tt} \\ \text { Efisiensi Pengolahan } & : 5 \% \\ \text { BOD keluar } & : 22,8 \mathrm{mg} / \mathrm{lt} \\ \text { Waktu Tinggal (WTH) } & : 2 \mathrm{jam} \\ \text { Volume bak } & : 1,67 \mathrm{~m}^{3} \\ & \\ \text { Dimensi bak : } & : 1,5 \mathrm{~m} \\ \text { Lebar } & : 2,2 \mathrm{~m} \\ \text { Panjang } & : 2,0 \mathrm{~m} \\ \text { Kedalaman Air efektif } & \text { Chek: }\end{array}$


Waktu Tinggal (Retention Time) rata-rata $= \pm$ 2,16 Jam

Beban permukaan (surface loading) rata-rata $=$ 22,22 m3/m2.hari

Standar

Waktu tinggal 2 jam

Beban permukaan $=20-50 \mathrm{~m} 3 / \mathrm{m} 2$. hari. (JWWA)

Total Waktu Tinggal di dalam Reaktor Pengolahan Lanjut $=$ $=2.16 \mathrm{jam}+4,8 \mathrm{jam}+2,52 \mathrm{jam}+2.16 \mathrm{jam}=$ 11,64 Jam

Total Waktu Tinggal Di dalmsistem IPAL $=$ Waktu Tinggal Bak Ekualisasi + Waktu Tinggal Reaktor Anaerob + Waktu Tinggal Reaktor Pengolahan Lanjut

$=12 \mathrm{Jam}+5,52 \mathrm{Jam}+11,64 \mathrm{jam}=29,16 \mathrm{Jam}$.

\subsubsection{Media Pembiakan Mikroba}

$\begin{array}{ll}\text { Material } & : \text { PVC sheet } \\ \text { Ketebalan } & : 0,15-0,23 \mathrm{~mm} \\ \text { Luas Kontak Spsesifik } & : 200-226 \mathrm{~m} 2 / \mathrm{m} 3 \\ \text { Diameter lubang } & : 2 \mathrm{~cm} \times 2 \mathrm{~cm} \\ \text { Warna } & : \text { bening transparan. } \\ \text { Berat Spesifik } & : 30-35 \mathrm{~kg} / \mathrm{m} 3 \\ \text { Porositas Rongga } & : 0,98 \\ \text { Total Media Biofilter Yang Diperlukan }=10 \mathrm{~m}^{3}\end{array}$

\subsubsection{Pompa Air Sirkulasi}

Kapasitas
Tipe
Total Head
Jumlah
cadangan)
Listrik

\subsubsection{Blower Udara}

$\begin{array}{ll}\text { Kapsitas } & : 0,213 \mathrm{~m}^{3} \text { per menit } \\ \text { Total Head } & : 280 \mathrm{~cm} \text { air } \\ \text { Tipe } & : \text { HiBLOW } 60 \\ \text { Listrik } & : 100 \text { watt } \\ \text { Jumlah } & : 2 \text { unit }\end{array}$

\subsubsection{Bak Kontaktor Khlorine}

Unit IPAL Rumah sakit tersebut dapat dilengkapi dengan bak khlorinasi (bak kontaktor) yang berfungsi untuk mengkontakkan khlorine dengan air hasil pengolahan. Air limbah yang telah diolah sebelum dibuang ke saluran umum dikontakkan dengan khlorine agar mikroorganisme patogen yang ada di dalam air dapat dimatikan. Senyawa khlor yang digunakan adalah kaporit dalam bentuk tablet.
Dari hasil perhitungan di atas

- Diagram proses pengolahan air limbah rumah sakit Kombinasi biofilter anaerobaerob dapat dilihat seperti pada Gambar 4.

- Gambar Bak Ekulisasi dapat dilihat pada Gambar 5 dan Gambar 6.

- Penampang Biofilter Anaerobik untuk IPAL Rumah Sakit dapat dilihat pada Gambar 7 dan Gambar 8.

- Reaktor Biofilter Pengolahan Lanjut Untuk IPAL Rumah Sakit dapat dilihat pada Gambar 9 sampai dengan Gambar 15.

- Diagram Kelistrikan dapat dilihat pada Gambar 16.

- Media Biofilter dari bahan palstik tipe sarang tawon dapat dilitat seperti pada Gambar 17 .

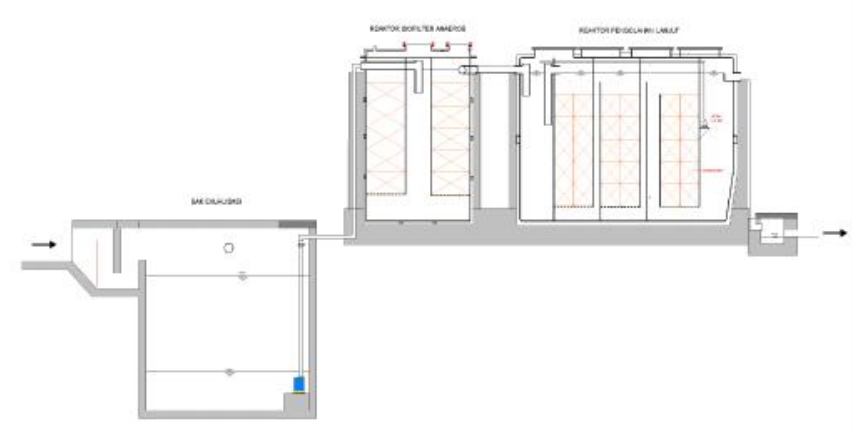

Gambar 4 : Diagram proses pengolahan air limbah rumah sakit Kombinasi biofilter anaerobaerob.

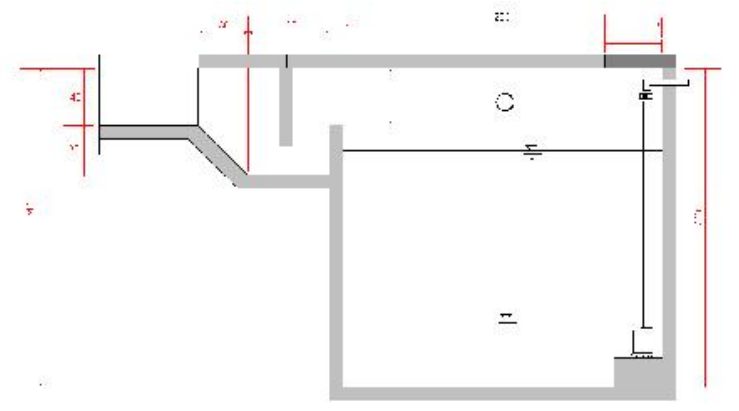

Gambar 5 : Potongan Melintang Bak Ekulaisasi

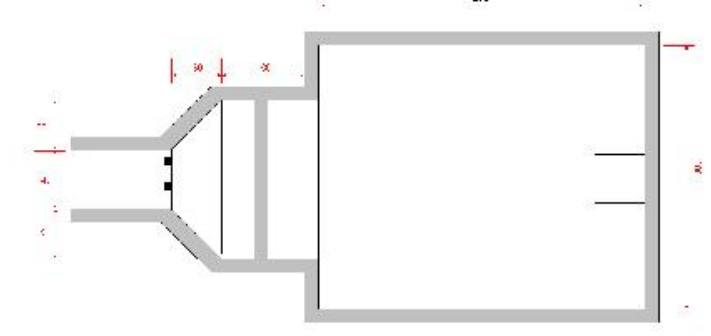

Gambar 6 : Bak ekualisasi (Tampak Atas). 


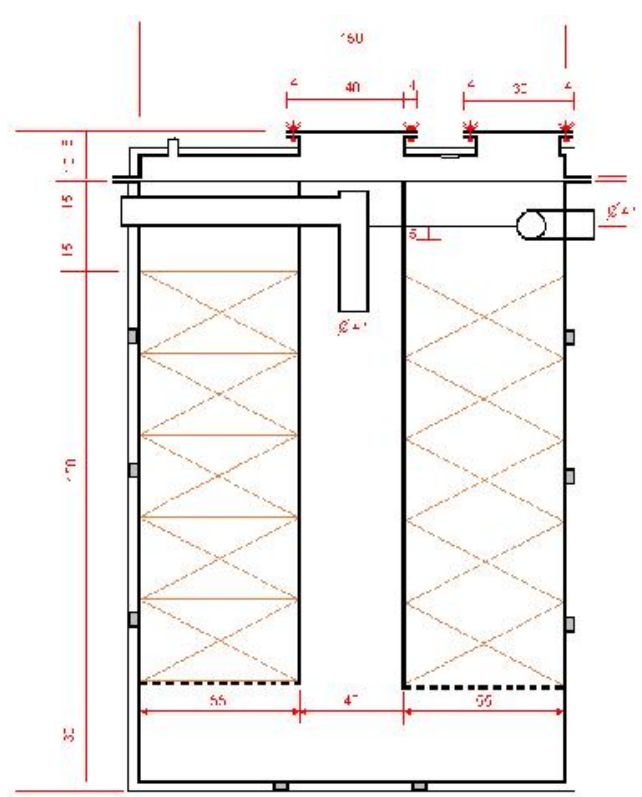

Gambar 7 : Penampang Biofilter Anaerobik untuk IPAL Rumah Sakit.

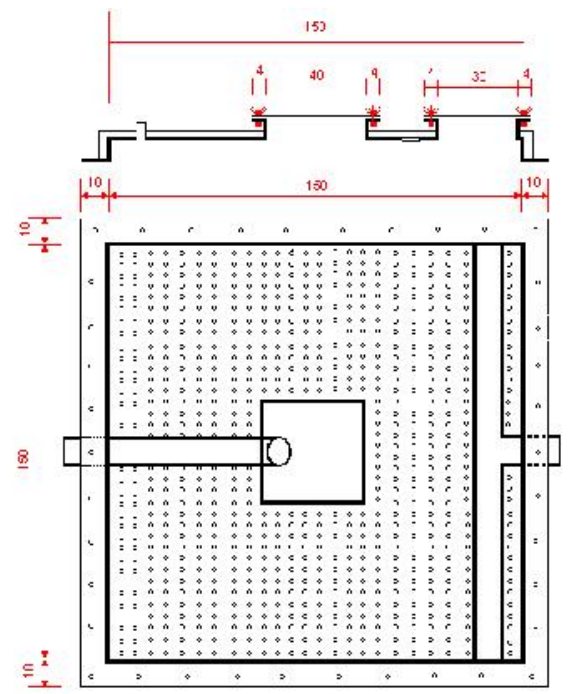

Gambar 8 : Penampang Biofilter Anaerobik untuk IPAL Rumah Sakit

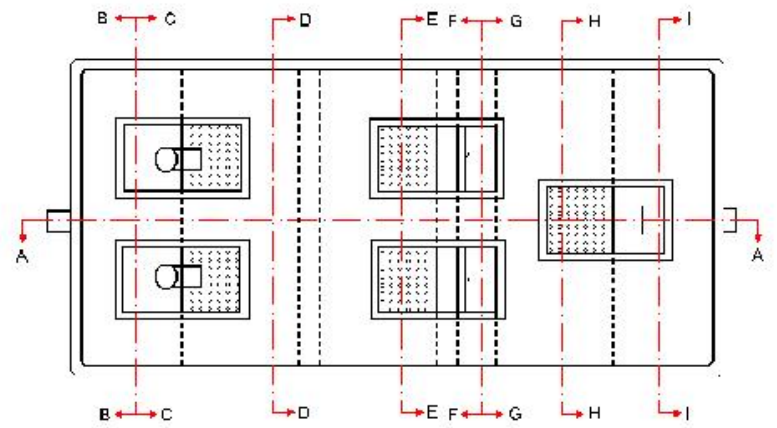

Gambar 9 : Reaktor Biofilter Pengolahan Lanjut Untuk IPAL Rumah Sakit, Tampak Atas.

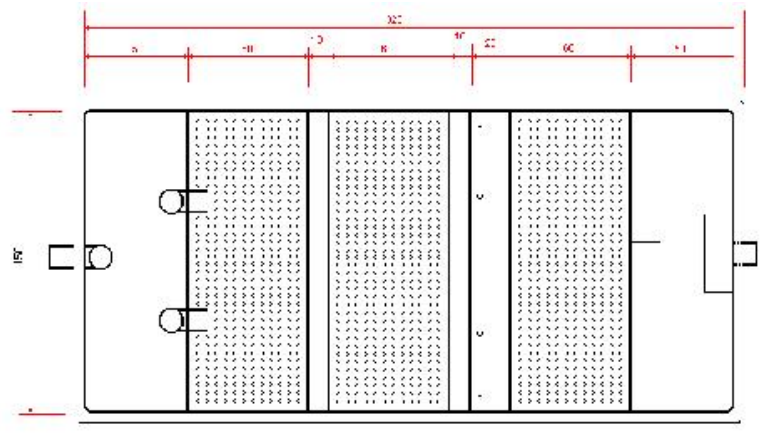

Gambar 10 : Reaktor Biofilter Pengolahan Lanjut Untuk IPAL Rumah Sakit, Tampak Atas.

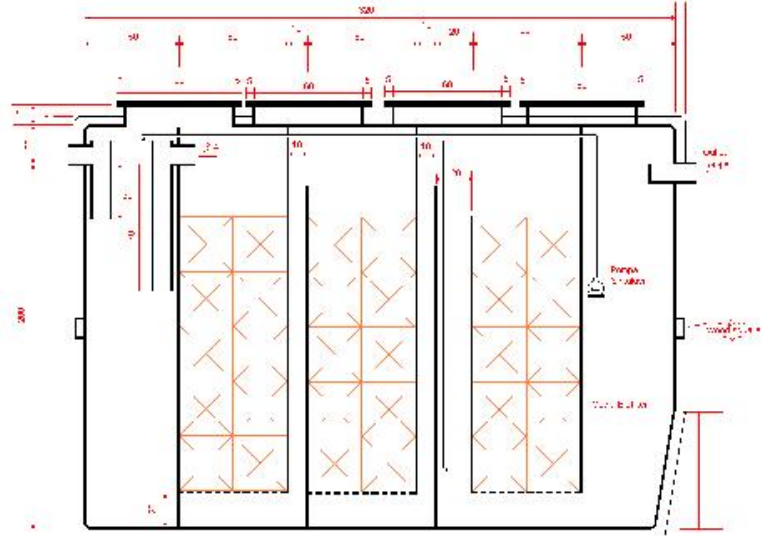

Gambar 11 : Reaktor Biofilter Pengolahan Lanjut Untuk IPAL Rumah Sakit, Potongan melintang.
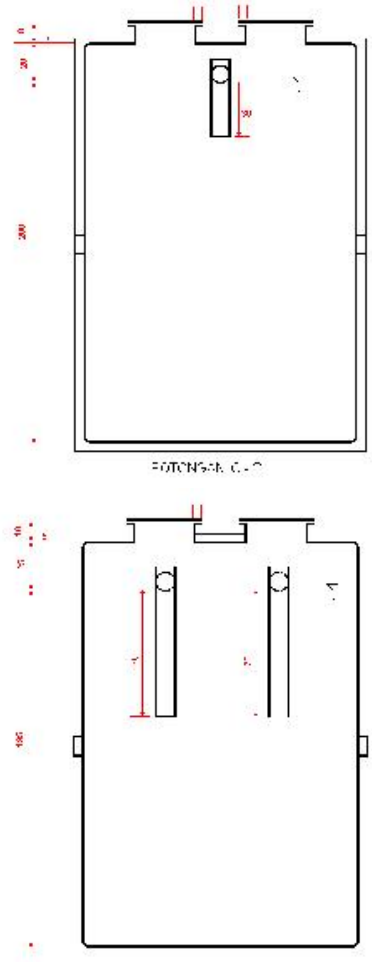

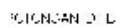

Gambar 12 : Potongan C -C Dan D-D Reaktor Biofilter Pengolahan Lanjut. 


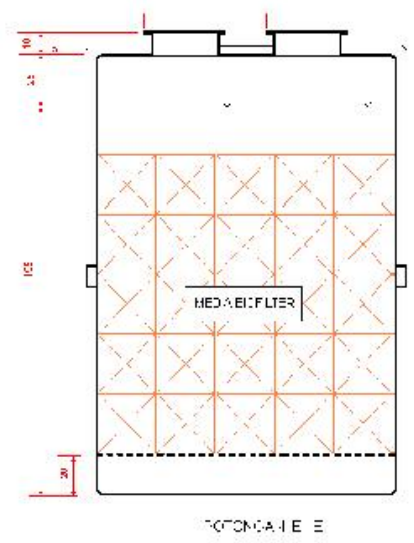

Gambar 13 : Potongan E-E

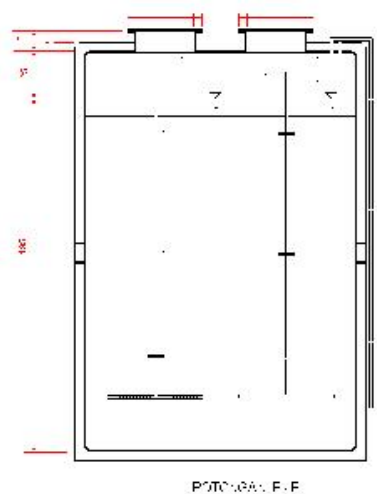

Gambar 14 : Potongan F - F Reaktor Biofilter Pengolahan Lanjut.
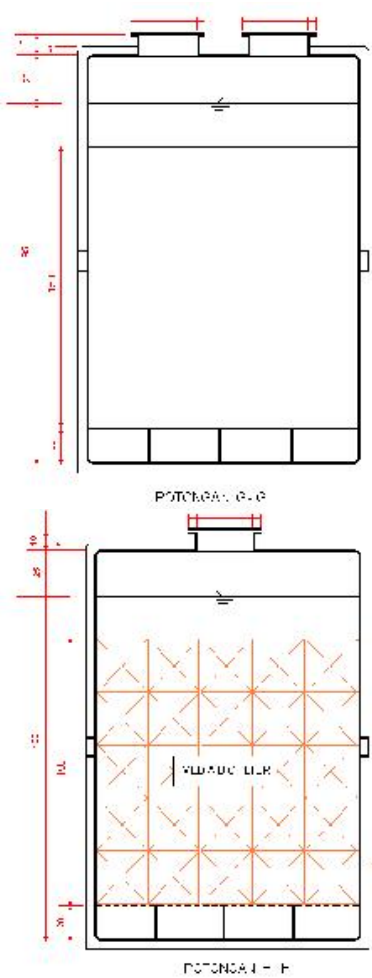

Gambar 14 : Potongan G - G Dan H - H Reaktor Biofilter Pengolahan Lanjut.

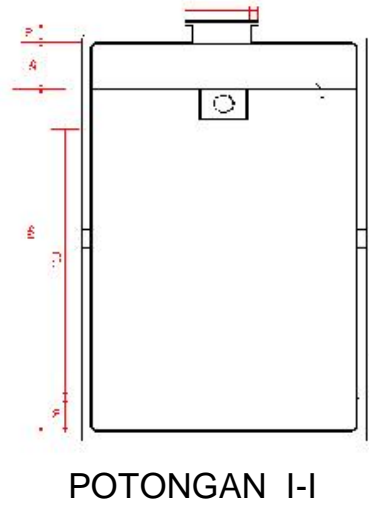

Gambar 15 : Potongan I - I Reaktor Biofilter Pengolahan Lanjut.

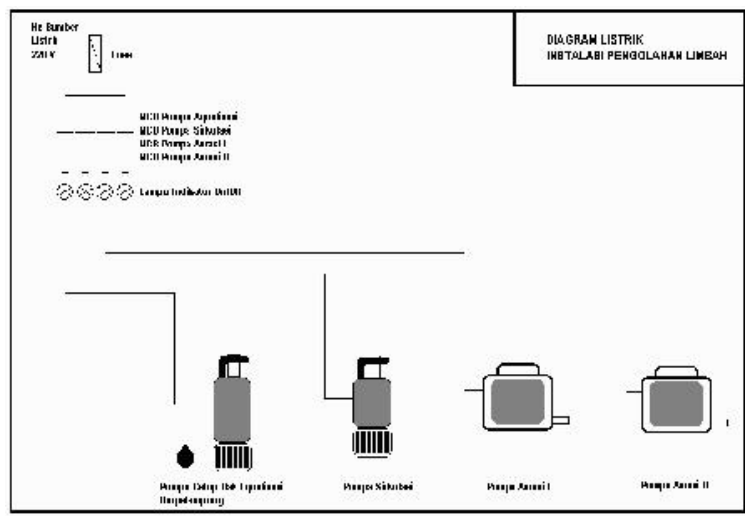

Gambar 16 : Diagram Kelistrikan

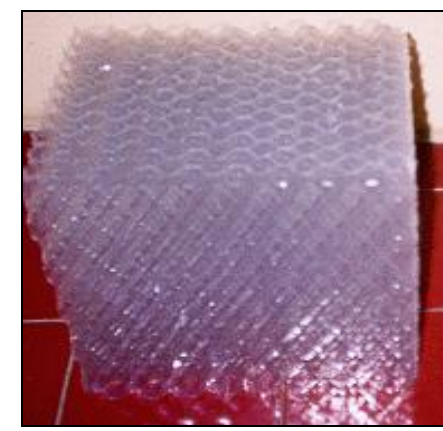

Gambar 17 : Media Biofilter dari bahan palstik tipe sarang tawon

\subsection{Spesifikasi Teknis IPAL Rumah Sakit Biofilter Anaerob-Aerob Kapasitas 20- $30 \mathrm{M}^{3}$ per hari.}

Berdasarkan perhitungan teknis seperti tersebut di atas maka spesifikasi teknis IPAL dan peralatannnya dapat diuraikan seperti berikut :

$\begin{array}{lc}\text { Kapasitas Rencana (Disain) } \\ \text { Kapasitas } & : 20-30 \mathrm{~m}^{3} / \text { hari } \\ \text { Influent BOD } & : 400 \mathrm{ppm} \\ \text { Influent SS } & : 300 \mathrm{ppm} \\ \text { Effluent BOD } & : 30 \mathrm{ppm}\end{array}$




$\begin{array}{ll}\text { Effluent SS } & : 20 \mathrm{ppm} \\ \text { Efisiensi Pengolahan } & : 90-95 \% \\ & \\ \text { Bak Ekualisasi } & \\ \text { Dimensi bak: } & : 2 \mathrm{~m} \\ \text { Lebar } & : 2 \mathrm{~m} \\ \text { Panjang } & : 2,5 \mathrm{~m} \\ \text { Kedalaman } & : 0,5 \mathrm{~m} \\ \text { Tinggi ruang bebas } & : \text { Bata Beton cor } \\ \text { Bahan } & \end{array}$

Unit Reaktor Anaerob

Dimensi Reaktor :

$\begin{array}{ll}\begin{array}{l}\text { Panjang } \\ \text { Lebar }\end{array} & : 150 \mathrm{~cm} \\ \text { Tinggi } & : 150 \mathrm{~cm} \\ \text { Bahan } & : 230 \mathrm{~cm} \\ & : \text { Fiber Rainforced Palstic } \\ \text { Media } & \begin{array}{l}\text { (FRP) } \\ \text { Plastic Media (type } \\ \text { honeycomb tube) }\end{array} \\ \text { Spesific Area } & : 200-226 \mathrm{~m}^{2} / \mathrm{m}^{3}\end{array}$

Unit Reaktor Pengolahan Lanjut (Aerob)

Dimensi Reaktor :

$\begin{array}{ll}\text { Panjang } & : 320 \mathrm{~cm} \\ \text { Lebar } & : 150 \mathrm{~cm} \\ \text { Tinggi } & : 230 \mathrm{~cm} \\ \text { Bahan } & : \text { Plastic Media (type: } \\ \text { honeycomb tube) } & \\ \text { Spesific Area } & : 200-226 \mathrm{~m}^{2} / \mathrm{m}^{3}\end{array}$

\section{Peralatan :}

a. Blower Udara

$\begin{array}{ll}\text { Tipe } & : \text { HIBLOW } 60 \\ \text { Kapasitas } & : 60 \text { liter per menit } \\ \text { Listrik } & : 100 \text { watt, } 220 \text { volt. } \\ \text { Jumlah } & : 2 \text { unit }\end{array}$

\section{b. Pompa Air Limbah}

$\begin{array}{ll}\text { Tipe } & \text { : Submersible Pump (Pompa } \\ \text { Celup) } \\ \text { Kapasitas } & : 20-40 \text { liter/menit } \\ \text { Listrik } & : 100 \text { watt } \\ \text { Total Head } & : 8 \text { meter } \\ \text { Jumlah } & : 1 \text { unit } \\ \text { Material } & : \text { Stainless Steel }\end{array}$

\section{c. Pompa Sirkulasi}

$\begin{array}{ll}\text { Tipe } & : \text { Submersible Pump } \\ \text { Kapasitas } & : 20 \text { liter/menit } \\ \text { Listrik } & : 75 \text { watt } \\ \text { Total Head } & : 6-8 \text { meter } \\ \text { Jumlah } & : 1 \text { unit }\end{array}$

\section{Media Biofilter}

$\begin{array}{ll}\text { Material } & : \text { PVC sheet } \\ \text { Ketebalan } & : 0,15-0,23 \mathrm{~mm} \\ \text { Luas Kontak Spsesifik } & : 200-226 \mathrm{~m} 2 / \mathrm{m3}\end{array}$

$\begin{array}{ll}\begin{array}{ll}\text { Diameter lubang } \\ \text { Warna }\end{array} & \begin{array}{l}: 2 \mathrm{~cm} \times 2 \mathrm{~cm} \\ \text { : bening / } \\ \text { transparan. }\end{array} \\ \text { Berat Spesifik } & : 30-35 \mathrm{~kg} / \mathrm{m} 3 \\ \text { Porositas Rongga } & : 0,98 \\ \text { Jumlah } & : 10 \mathrm{M} 3\end{array}$

\section{PEMBANGUNAN PERCONTOHAN IPAL RUMAH SAKIT KAPASITAS 20-30 M3 PER HARI}

Lokasi percontohan dibanguan di rumah sakit umum Elizabeth, Sitobondo, Jawa Timur. Kontruksi IPAL yang telah terpasang dapat dilihat seperti pada Gambar 18 sampai dengan Gambar 24.

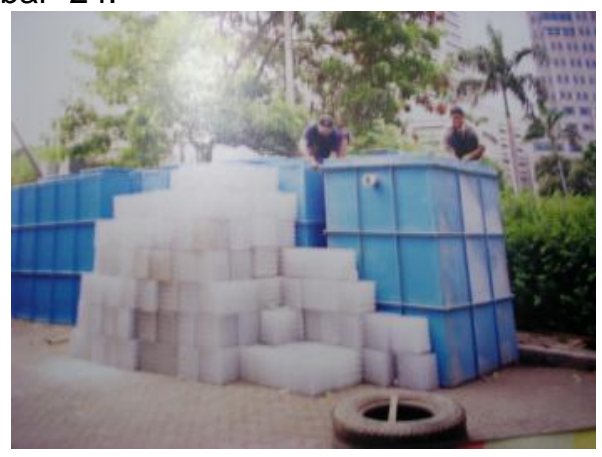

Gambar 18: Reaktor IPAL dan media sarang tawon.

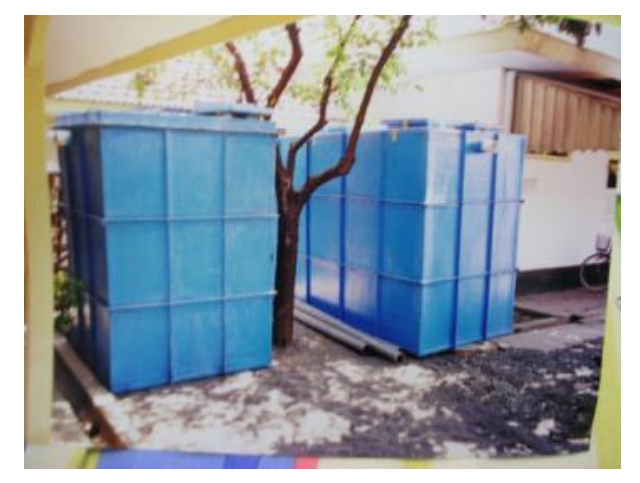

Gambar 19 : Reaktor IPAL sebelum dipasang.

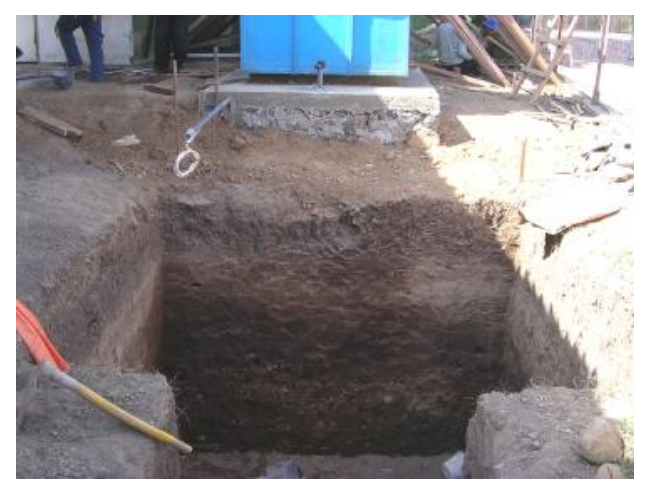

Gambar 20 : Pembuatan bak ekualisasi. 


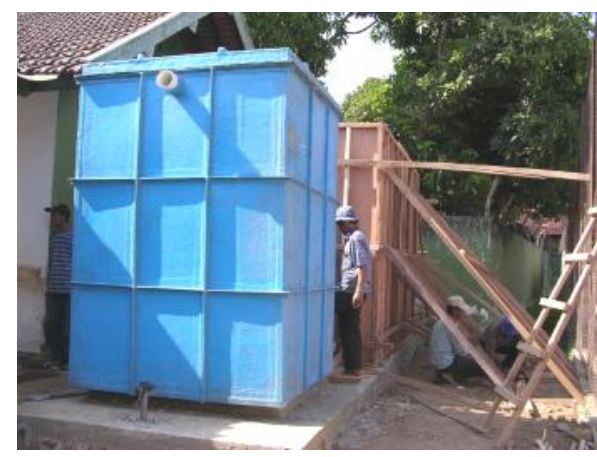

Gambar 21: Reaktor IPAL telah diletakkan di atas pondasi IPAL

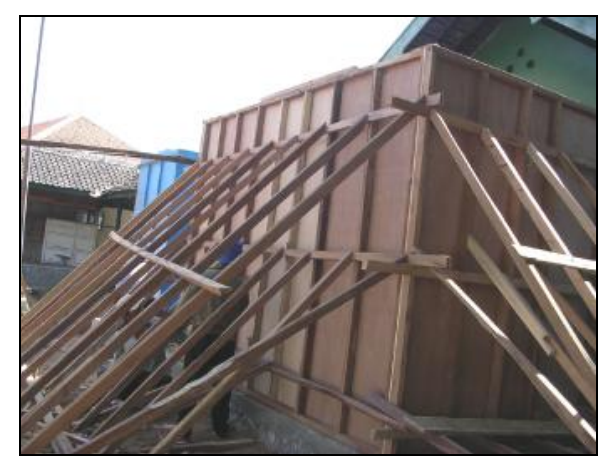

Gambar 22 : Bekesting reaktor IPAL

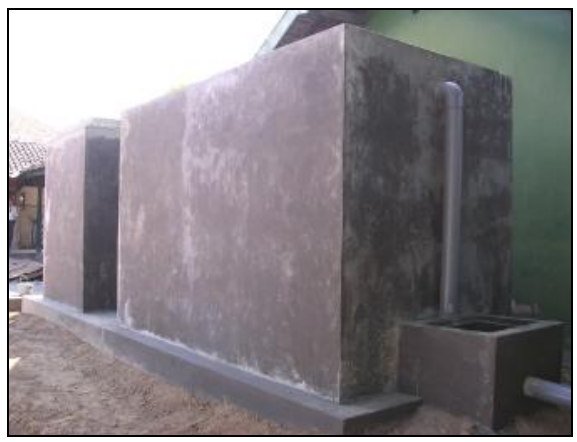

Gambar 23: Reaktor IPAL dan bak equalisasi telah dicor pada lokasinya

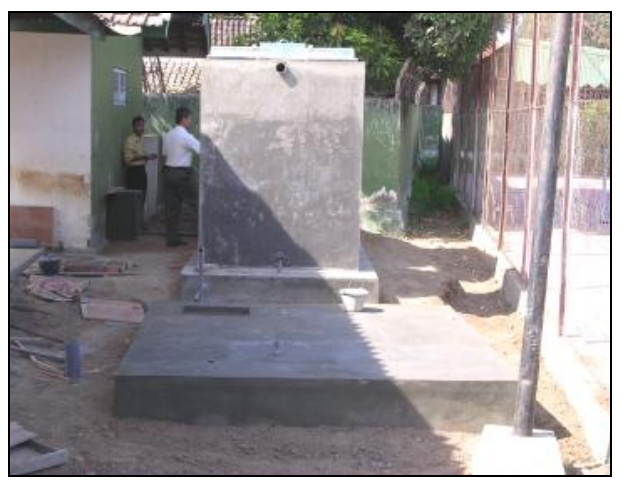

Gambar 24: Reaktor IPAL yang telah terpasang.

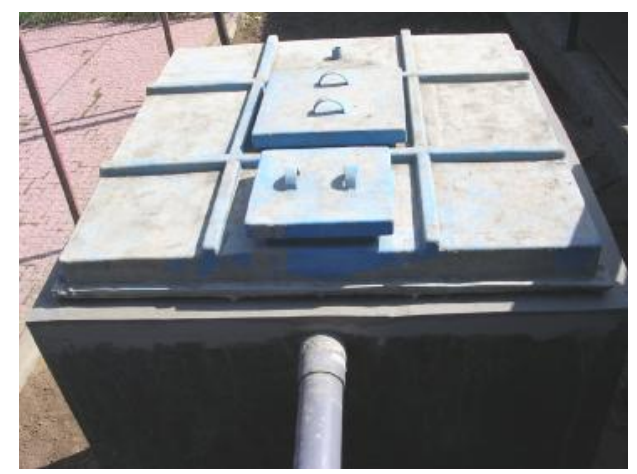

Gambar 25: Reaktor IPAL terlihat dari bagian atas

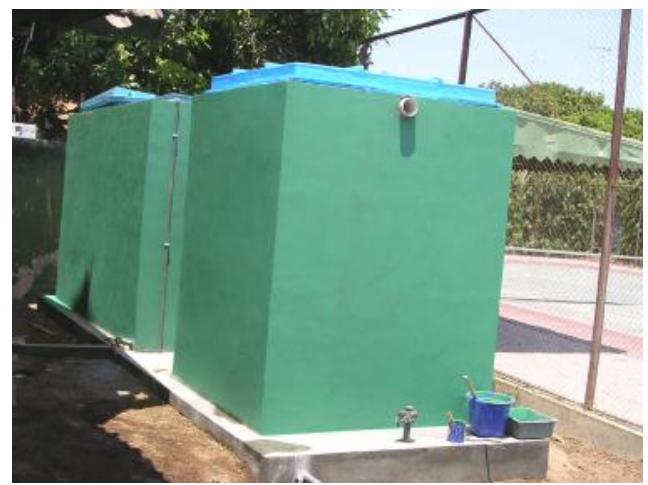

Gambar 26: Reaktor IPAL telah terpasang rapi

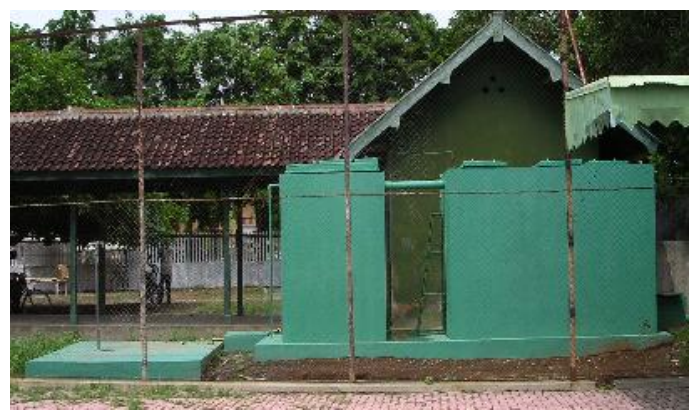

Gambar 27: IPAL R.S. Elizabeth-Situbondo

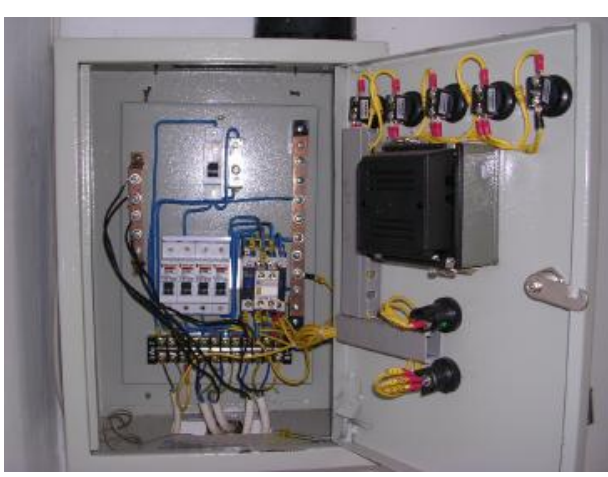

Gambar 28: Kontrol Panel 


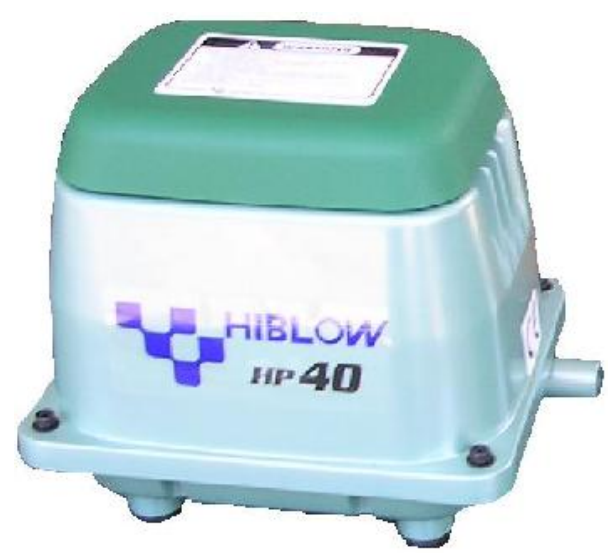

Gambar 29: Blower udara

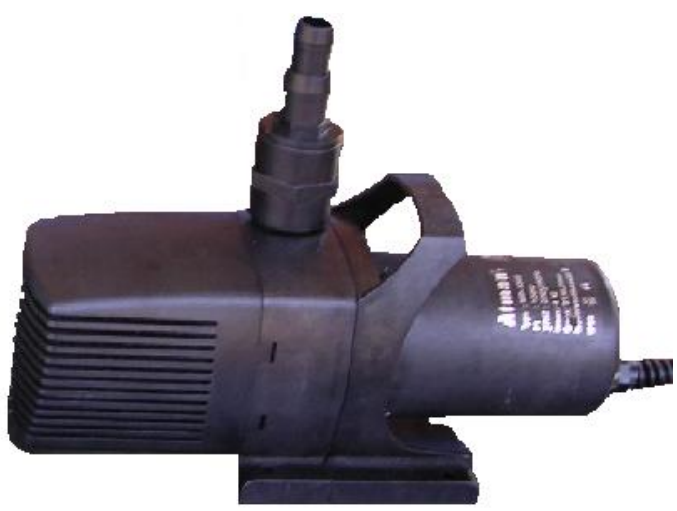

Gambar 30: Pompa recycle

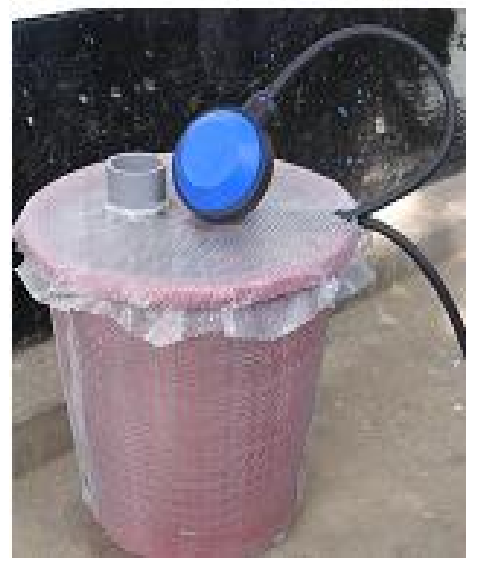

Gambar 31: Pompa inlet dan pompa bak kontrol yang dilengkapi dengan saringan pelindung.

\section{UJI COBA IPAL}

Uji coba dilkukan di Rumah Sakit Elizabeth, Situbondo. Air yang akan diolah adalah seluruh air yang dihasilkan oleh kegiatan rumah sakit yakni air yang berasal dari dapur, laundry, air limbah dari kegiatan klinis, air limpasan tangki septik dan lainnya. Untuk Air limbah dari limbah laboratorium tidak dimasukkan ke dalam sistem IPAL. Pengambilan dan pengujian kualitas air dilakukan setelah IPAL beroperasi selama tiga bulan.

Berdasarkan hasil uji coba IPAL RS Elizabeth, Situbondo didapatkan hasil sebagai berikut yakni konsentrasi COD $170 \mathrm{mg} / \mathrm{l}$ turun menjadi $30 \mathrm{mg} / \mathrm{l}$, konsentrasi BOD di dalam air limbah $100 \mathrm{mg} / \mathrm{l}$ turun menjadi $12 \mathrm{mg} / \mathrm{l}$, sedangkan konsentrasi zat padat tersuspensi (TSS) dari $150 \mathrm{mg} / \mathrm{l}$ turun menjadi $2 \mathrm{mg} / \mathrm{l}$.

Dari hasil tersebut dapat dilihat bahwa pengolahan air limbah rumah sakit dengan proses biofilter anaerob-aerob dapat menurunkan konsentrasi COD, BOD serta zat padat tersuspensi dengan baik. Selain itu juga dapat menurunkan kandungan amoniak dan deterjen. Kualitas air limbah sebelum dan sesudah pengolahan secara lengkap dapat dilihat pada Tabel 1.

Tabel 1: Hasil analisa air limbah rumah sakit Elizabeth, Situbondo sebelum dan sesudah pengolahan.

\begin{tabular}{|c|l|c|c|}
\hline No & PARAMETER & $\begin{array}{c}\text { AIR LIMBAH } \\
(\mathrm{mg} / \mathrm{l})\end{array}$ & $\begin{array}{c}\text { AIR OLAHAN } \\
(\mathrm{mg} / \mathrm{l})\end{array}$ \\
\hline 1 & BOD & 100 & 12 \\
\hline 2 & COD & 170 & 30 \\
\hline 3 & $\begin{array}{l}\text { Total padatan } \\
\text { tersuspensi } \\
\text { (TSS) }\end{array}$ & 150 & 2 \\
\hline 4 & $\mathrm{NH}_{3}$-bebas & 0,46 & 0,00003 \\
\hline 5 & $\begin{array}{l}\text { MBAS } \\
\text { (deterjen) }\end{array}$ & 2,56 & 0,398 \\
\hline 6 & Phenol & 0,05 & 0,0 \\
\hline 7 & Sisa Khlor & 0,0 & 0,0 \\
\hline 8 & $\begin{array}{l}\text { Phosphat } \\
\text { (ortho) }\end{array}$ & 2,33 & 1,5 \\
\hline & \multicolumn{2}{|c|}{} \\
\hline
\end{tabular}

Catatan : contoh diambil setelah IPAL beropersi selama 3 bulan.

\section{PENUTUP}

Berdasarkan hasil pengamatan selama lebih dari empat bulan opersi, pengolahan air limbah rumah sakit dengan sistem kombinasi proses biofilter Anaerob-Aerob mempunyai beberapa keunggulan antara lain yakni :

$>$ Efisiensi pengolahan cukup tinggi.

> Pengelolaannya sangat mudah.

> Biaya operasinya rendah, untuk kapasitas IPAL $20 \mathrm{M}^{3}$ per hari diperlukan dua unit blower masing-masing 60 watt.

$>$ Suplai udara untuk aerasi relatif kecil.

> Dapat digunakan untuk air limbah dengan beban BOD yang cukup besar.

> Dapat menghilangan padatan tersuspensi (SS) dengan baik. 
$>$ Tahan terhadap perubahan beban pengolahan secara mendadak.

\section{DAFTAR PUSTAKA}

- $\quad$-----, “ Gesuidou Shissetsu Sekkei Shisin to Kaisetsu “, Nihon Gesuidou Kyoukai, 1984.

- -----, "Pekerjaan Penentuan Standard Kualitas Air Limbah Yang Boleh Masuk Ke Dalam Sistem Sewerage PD PAL JAYA", Dwikarasa Envacotama-PD PAL JAYA, 1995.

- Anonim. (1995), "Surat Keputusan Menteri Negara Lingkungan Hidup, Kep51/MENKLH/10/1995". Baku Mutu Limbah Cair Bagi Kegiatan Rumah Sakit. Badan Pengendalian Dampak Lingkungan. Jakarta.

- Arvin, E dan Herremoes., "Concepts and Models for Biofilm Reactor Performance", Water Science Technology, Vol.22, No.1/2, pp. 171-192, 1990.

- Benefield, Larry, D and Randal, Cliiford.W. (1990), "Biological Proccesses Design For Wastewater Treatment". Prentice Hall, New York.

- Casey, T.J.(1997). "Unit Treatment Process In Water and Wastewater Engineering". University College Dublin, Ireland : John wiley and Sons Ltd.

- Dojlido, jan R, and Best, Gerald A. (1993). "Chemistry of Water and Wastewater Pollution”. England. Ellis Horwood Limited.

- Droste, Ronald R. (1997). "Theory and Practice of Water and Wastewater Treatment". John wiley and Sons Ltd.Toroto, Canada.

- Fair, Gordon Maskew et.al., "Elements Of Water Supply And Waste Water Disposal", John Willey And Sons Inc., 1971.

- Gouda T., “Suisitsu Kougaku - Ouyouben”, Maruzen kabushiki Kaisha, Tokyo, 1979.

- Grady, C.P.L and Lim, H.C.(1980). "Biological Wastewater Treatment", Marcel Dekker Inc. New York.

- Henze. (1983). "Anaerobic Treatment of Wastewater in Fixed Bed Reactor". Water Science Technology, Vol.15, 1983.

- Horan, N.J.(1990). "Biological Wastewater Treatment systems : Theory and Operation". University of Leeds, England. John Wiley \& Sons Ltd.

- Metclaf And Eddy (1978). "Waste Water Engineering", Mc Graw Hill.
- Mosey, F.E. (1983), Water Science Technology, Vol.15, 1983.

- Reynolds, T.D. (1982). "Unit Operations and Processes in Environmental Engineering". Boston : B/C Engineering Division.

- Said,N.I. (2000). "Pengolahan Air Limbah dengan Proses Biofilter Anaerob-Aerob". Jurnal Teknologi Lingkungan Vol.1 No.2. Jakarta.

- Sueishi T., Sumitomo H., Yamada K., dan Wada Y., " Eisei Kougaku " (Sanitary Engineering), Kajima Shuppan Kai, Tokyo, 1987.

- Viessman W, Jr., Hamer M.J., “ Water Supply And Polution Control ", Harper \& Row, New York, 1985. 